\title{
PRIVILEGES OF FELLOWS.
}

Fellows have Personal Admission to the Gardens upon signing their names in the book at the entrance gate, and may introduce Two Companions daily.

The Wife or Husband of a Fellow can exercise these privileges in the absence of the Fellow.

Until further notice, Fellows will receive 40 undated Green Cards, available on any Sunday or week-day up to the end of February of the year following the year of issue, and 20 White Cards available on any week-day up to the same date. Twenty of the Green Cards may be exchanged for a book containing two Orders for each Sunday in the year. Twenty White Cards may be exchanged for a book of dated Saturday Orders, each Order available for any day except Sunday in the week ending with the Saturday for which it is dated. Special children's tickets will no longer be issued, but the Green and White Cards will be perforated, and each half will be valid for a Child under twelve years of age. It is particularly requested that Fellows will sign every ticket before it goes out of their possession. Unsigned tickets are not available.

FelLows are not allowed to pass in friends on their written order or on presentation of their visiting cards.

FelLows have the privilege of receiving the Society's ordinary Publications issued during the year upon payment of an additional Subscription of One Guinea. This Subscription is due upon the 1st. of January, and must be paid before the day of the Anniversary Meeting, after which the privilege lapses. Fellows are likewise entitled to purchase these Publications at 25 per cent. less than the price charged to the public. A further reduction of 25 per cent. is also made upon all purchases of Publications issued prior to 1881 , if above the value of Five Pounds.

Fellows also have the privilege of subscribing to the Annual Volume of 'The Zoological Record,' which gives a list of the Works and Publications relating to Zoology in each year, for the sum of One Pound Ten Shillings. Separate divisions of volumes 39 to 42 can also be supplied. Full particulars of these publications can be had on application to the Secretary.

Fellows may obtain a Transferable Ivory Ticket admitting two persons, available throughout the whole period of Fellowship, on payment of Ten Pounds in one sum. A second similar ticket may be obtained on payment of a further sum of Twenty Pounds. 
Any FeLLow who intends to be absent from the United Kingdom during the space of at least one year, may, upon giving to the Secretary notice in writing, have his or her name placed upon the "dormant list," and will then be called upon to pay an annual subscription of $£ 1$ only during such absence, but after three years must make a further application to be retained on that list.

Any Fellow, having paid all fees due to the Society, is at liberty to withdraw his or her name upon giving notice in writing to the Secretary.

Ladies or Gentlemen wishing to become Fellows of the Society are requested to communicate with "The Secretary."

P. CHALMERS MITCHELL,

Secretary.

Regent's Park, London. N.W.

December, 1914.

MEETINGS

OF THE

ZOOLOGICAL SOCIETY OF LONDON

FOR

SCIENTIFIC B USINESS.

1915.

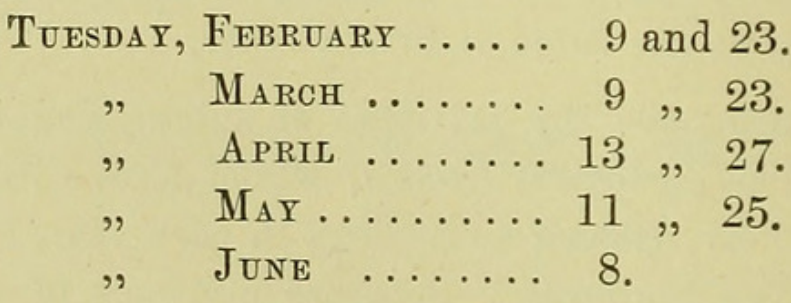

The Chair will be talcen at half-past Five o'clock precisely. 


\section{$2 \mathrm{BHL}$ Biodiversity Heritage Library}

Mitchell, P. Chalmers. 1914. "Privileges of fellows." Proceedings of the Zoological Society of London 1914, 3-4. https://doi.org/10.1111/j.1469-7998.1914.tb07720.x.

View This Item Online: https://www.biodiversitylibrary.org/item/99377

DOI: https://doi.org/10.1111/j.1469-7998.1914.tb07720.x

Permalink: https://www.biodiversitylibrary.org/partpdf/72221

\section{Holding Institution}

Smithsonian Libraries

\section{Sponsored by}

Biodiversity Heritage Library

\section{Copyright \& Reuse}

Copyright Status: Public domain. The BHL considers that this work is no longer under copyright protection.

This document was created from content at the Biodiversity Heritage Library, the world's largest open access digital library for biodiversity literature and archives. Visit BHL at https://www.biodiversitylibrary.org. 